\title{
Phenolic wastewater remediation employing nano zerovalent iron as a granular third electrode in an electrochemical reactor
}

\section{Shaimaa T Kadhum}

University of Technology, Baghdad, Iraq

\section{Ghayda Y Alkindi}

University of Technology, Baghdad, Iraq

Talib M Albayati ( $\sim$ Talib.M.Naieff@uotechnology.edu.iq )

University of Technology https://orcid.org/0000-0001-5619-7760

\section{Research}

Keywords: Electrochemical technique, 3D electrode, Nano zerovalent iron, Phenol, Wastewater treatment

Posted Date: September 17th, 2020

DOI: https://doi.org/10.21203/rs.3.rs-68838/v1

License: (1) This work is licensed under a Creative Commons Attribution 4.0 International License.

Read Full License 


\title{
Phenolic wastewater remediation employing nano zerovalent iron as a granular third electrode in an electrochemical reactor
}

\author{
Shaimaa T. Kadhum ${ }^{a}$, Ghayda Y. Alkindi ${ }^{b}$,Talib M. Albayati ${ }^{c} *$ \\ a,b Department of Civil Engineering, University of Technology, 52 Alsinaa St., PO Box 35010, \\ Baghdad, Iraq \\ c Department of Chemical Engineering, University of Technology, 52 Alsinaa St., PO Box \\ 35010, Baghdad, Iraq \\ (a)e-mail: 40124@ uotechnology.edu.iq \\ (b) e-mail: 40126@uotechnology.edu.iq \\ c* Corresponding author e-mail: Talib.M.Naieff@uotechnology.edu.iq
}

\begin{abstract}
The rise in toxic industrial and domestic wastewater due to urbanization makes it necessary to pursue new, alternative routes for the removal of refractory pollutants. In this study, both unsupported nano zerovalent iron (NZVI) and silty clay-supported nano zerovalent iron (SCNZVI) were employed as a granular third electrode (3-D) in an electrochemical reactor. The electrochemical system with two aluminum electrodes as anode and cathode was performed as a granular third electrode treatment process to degrade aqueous phenol. The maximum removal rate of phenol using the tow electrodes electrochemical process (2-D) was $82 \%$. The optimum conditions in a 2-D electrode were as follows: $\mathrm{pH}=4$, electrolysis time $=30 \mathrm{~min}$, current density $=50 \mathrm{~mA} / \mathrm{cm}^{2}$, electrode distance $=4 \mathrm{~cm}$, and phenol concentration $=0.5 \mathrm{~g} / \mathrm{L}$. It was concluded that the 3-D electrode system exhibited high efficiency in removing phenolic wastewater in a third electrode system. The optimum conditions were as follows: $\mathrm{pH}=2$, electrolysis time $=30$ min, current density $=50 \mathrm{~mA} / \mathrm{cm}^{2}$, electrode distance $=4 \mathrm{~cm}$, and phenol concentration $=0.5$ $\mathrm{g} / \mathrm{L}$. The maximum removal efficiencies of phenol in the presence of a 3-D electrode with doses of $\mathrm{NZVI}=1 \mathrm{~g} / \mathrm{L}$ or $\mathrm{SC}-\mathrm{NZVI}=1.25 \mathrm{~g} / \mathrm{L}$ were 96.1 and $97.8 \%$, respectively.
\end{abstract}

Keywords: Electrochemical technique; 3D electrode; Nano zerovalent iron; Phenol; Wastewater treatment. 


\section{Introduction}

Phenol and its compounds exist in wastewater of various industries, including petroleum refineries, petrochemical industries, coking operations, pharmaceutical production and phenolic resins industries [1]. According to the US Environmental Protection Agency (EPA) and the National Pollutant Release Inventory (NPRI) of Canada, phenol is classified as a priority pollutant $[2,3]$. People exposed to phenol acutely or chronically may suffer adverse health consequences, which may be quite serious depending on the degree of exposure [4]. Several techniques have been used to remove phenol from water and wastewater, including chemical oxidation [5, 6], microbial degradation [7, 8], membrane separation [9], photocatalytic degradation [10], solvent extraction [11], ultrasonic degradation [12], enzymatic polymerization [13], Fenton-like reactions [14], adsorption [15, 16], and electrochemical oxidation [17, 18].

In general, an electrooxidation system includes an oxidation process at the anode and a reduction process at the cathode (redox reaction). Additionally, the electrooxidation processes used for removing organic materials from wastewater depend upon the potential of gaining partial degradation or full mineralization by using anodic oxidation [19]. Electrooxidation processes can be divided into direct (andic oxidation) and indirect (using intermediary redox reagents) pathways [20]. In recent years, the green synthesis of nano zerovalent iron (NZVI) and its potential as an adsorbent have gained considerable attention. This interest is due to their natural, eco-friendly, low cost, and efficiency as an adsorbent. The high surface energy, high conductivity, and large specific surface area of nano zerovalent iron make it a useful alternate as a granulated electrode in wastewater treatment [21]. Unfortunately, NZVI particles without any modification are inclined to aggregate and oxidize due to van der Waals and magnetic attraction forces [22], thus decreasing their performance in application. Also, employing bare NZVI in the wastewater treatment process will likely cause a rapid loss of nano zerovalent iron as well as a high concentration of iron ions [23]. Hence, it is necessary to support NZVI by applying it onto a material that can decrease iron leaching and elongate the lifespan of the NZVI [24].

Recently, the electrochemical technique has gained considerable attention in wastewater remediation as a result of its quality, simplicity, and eco-friendly character in the removal of refractory organic pollutants [25]. However, the conventional electrochemical technique is considered unworkable because of its low current density. Therefore, the addition of a granular electrode to the traditional electrochemical unit is deemed an excellent improvement to enhance 
the efficiency and raise the current density of the electrochemical process [26]. The space between the granular electrodes in the electrochemical process that employed granular electrodes (3-D) systems was shorter, which allowed for more rapid electron transfer and treatment [25]. For these reasons, many researchers have been reporting excellent results using a 3-D electrochemical technique as a tertiary process in wastewater treatment [27, 28, 29].

In this study, NZVI and silty clay-supported nano zerovalent iron (SC-NZVI) synthesis and characterization are reported. Due to their large specific surface area, both NZVI and SC-NZVI have proved to be highly reactive and efficient adsorbents, which makes them both excellent candidates for use as a third electrode. Furthermore, the efficiency of NZVI and SC-NZVI as granular third electrodes for the removal of aqueous phenol was examined. Various significant operating conditions were optimized, such as $\mathrm{pH}$, electrolysis time, current density, electrode plate distance, granular electrode dose, and phenol concentration.

\section{Materials and Methods}

\subsection{Materials}

The source of polyphenol used in this work was the commercial leaves of green tea. Ferric chloride anhydrous $\left(\mathrm{FeCl}_{3}\right)$, phenol crystal $\left(\mathrm{C}_{6} \mathrm{H}_{5} \mathrm{OH}\right), 0.01 \mathrm{M}$ sodium hydroxide $(\mathrm{NaOH}), 0.01$ M sulfuric acid $\left(\mathrm{H}_{2} \mathrm{SO}_{4}\right)$, sodium sulfate $\left(\mathrm{Na}_{2} \mathrm{SO}_{4}\right)$ and deionized water were also used. All chemicals were purchased from Thomas Baker (India). The natural silty clay was obtained from Mosul, Iraq.

\subsection{Synthesis of NZVI and SC-NZVI}

In this study, NZVI and SC-NZVI were synthesized according to the methods used in our previous study, which has been submitted for publication. The synthesis methods are demonstrated in Fig. 1.

Fig. 1. Synthesis methods of (a) NZVI and (b) SC-NZVI.

\subsection{Characterization of NZVI and SC-NZVI}

The characterization of the prepared adsorbents NZVI and SC-NZVI was achieved using the following: X-ray diffraction (XRD), scanning electron microscopy (SEM), Fourier transform 


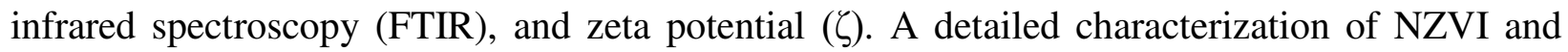
SC-NZVI is given in our previous study.

\subsection{Electrolytic cell}

The electrolytic cell used in this work is illustrated in Fig. 2. A reaction tank was made of a glass box, with dimensions $10 \times 6 \times 5 \mathrm{~cm}$. Two parallel aluminum plates $(2.5 \times 3 \times 0.1 \mathrm{~cm})$ with good electrochemical stability were used as parallel anode and cathode electrodes. This study also used a 60V 5A DC power supply (Maisheng MS-605D) and magnetic stirrer.

Fig. 2. Electrochemical apparatus.

\subsection{Batch experiments}

The performance of the NZVI and SC-NZVI as granulated electrodes in an electrochemical reactor to remove an aqueous phenol was evaluated by two groups of batch experiments. The first group researched the electrochemical processes without any modification. The second group studied the electrochemical processes in the presence of a granulated electrode (i.e., NZVI or SC-NZVI). All experiments were performed with $250 \mathrm{ml}$ of deionized water and $0.25 \mathrm{~g} / \mathrm{l}$ of the electrolyte $\left(\mathrm{Na}_{2} \mathrm{SO}_{4}\right)$. Experimental solutions were made by dissolving a specific weight of phenol in deionized water. The $\mathrm{pH}$ was adjusted using $0.1 \mathrm{~N} \mathrm{NaOH}$ and $0.1 \mathrm{~N} \mathrm{H}_{2} \mathrm{SO}_{4}$ solutions. For the second set of experiments, a specific weight of NZVI or SCNZVI was added to the prepared solution of the specific concentration of phenol $\left(\mathrm{C}_{6} \mathrm{H}_{5} \mathrm{OH}\right)$ along with $\left(\mathrm{Na}_{2} \mathrm{SO}_{4}\right)$ and deionized water. The produced solution was agitated at $250 \mathrm{rpm}$ using a magnetic stirrer. Samples were filtered using a $0.45-\mu \mathrm{m}$ syringe filter. A calibration curve of the phenol was made by UV 9200 Biotech Engineering, with a maximum $\lambda$ of $268 \mathrm{~nm}$. Depending on the absorbance (measured by UV spectroscopy) and calibration curve, the concentration and removal rate of phenol were calculated.

$$
\text { Removal rate } \%=\frac{C_{\mathrm{o}}-C_{t}}{C_{\mathrm{o}}} \times 100
$$

where $\mathrm{C}_{\mathrm{o}}$ and $\mathrm{C}_{\mathrm{t}}$ are the concentration of phenol (mg/L) at times zero and $\mathrm{t}$, respectively.

\section{Results and Discussion}

\subsection{Electrochemical experiments}

\subsubsection{Effect of pH}


The initial $\mathrm{pH}$ value has a considerable influence on the removal rate of phenol [30]. The removal rates of phenol were determined in the $\mathrm{pH}$ range from 2-6 and at an initial phenol concentration of $0.5 \mathrm{~g} / \mathrm{L}$ and $0.25 \mathrm{~g} / \mathrm{L}\left(\mathrm{Na}_{2} \mathrm{SO}_{4}\right)$, temperature of $45^{\circ} \mathrm{C}$, current density (CD) of 40 $\mathrm{mA} / \mathrm{cm}^{2}$, and plate distance of $4 \mathrm{~cm}$. Fig. 3 shows the influence of the initial $\mathrm{pH}$ of the phenol solution on the removal rate of phenol. The removal rates of phenol had their lower value at both low and high $\mathrm{pH}$ values, while the maximum removal rate was at a $\mathrm{pH}$ of 4 . These results occurred because at the lower $\mathrm{pH}$ value, $\mathrm{Al}(\mathrm{OH})_{3}$ does not precipitate due to its amphoteric property [31]. Additionally, at the higher $\mathrm{pH}$ value, $\mathrm{Al}(\mathrm{OH})_{4}$ forms, and this compound is ineffective for phenol adsorption [32].

Fig. 3. Effect of $\mathrm{pH}$ on the phenol removal percentage.

\subsubsection{Effect of electrolysis time}

The effect of the electrolysis time on the removal rate of phenol was investigated over $90 \mathrm{~min}$ and at an initial phenol concentration of $0.5 \mathrm{~g} / \mathrm{L}$ and $0.25 \mathrm{~g} / \mathrm{L}\left(\mathrm{Na}_{2} \mathrm{SO}_{4}\right)$, temperature of $45^{\circ} \mathrm{C}, \mathrm{pH}$ of $4, \mathrm{CD}$ of $40 \mathrm{~mA} / \mathrm{cm}^{2}$, and plate distance of $4 \mathrm{~cm}$ as initial conditions, as illustrated in Fig. 4 . The removal rates of phenol increased with the elongation of the electrolysis time until $30 \mathrm{~min}$. However, there was no significant increase in the removal rate of phenol after this time. After a specific time within the electrochemical process, the reduction in the concentration of pollutants leads to a decrease in the chance of contact with the electrode, which reduces the removal rate. Another potential cause is the formation of intermediate recalcitrant compounds due to the insufficient oxidation of organics [33].

Fig. 4. Effect of the electrolysis time on the removal rate of phenol.

\subsubsection{Effect of current density}

The experiments were conducted with a current density (CD) from 20 to $60 \mathrm{~mA} / \mathrm{cm}^{2}$ and with an initial phenol concentration of $0.5 \mathrm{~g} / \mathrm{L}$ and $0.25 \mathrm{~g} / \mathrm{L} \mathrm{Na}_{2} \mathrm{SO}_{4}$, temperature of $45^{\circ} \mathrm{C}, \mathrm{pH}$ of 4 , electrolysis time of $30 \mathrm{~min}$, and plate distance of $4 \mathrm{~cm}$. As displayed in Fig. 5, the removal rate of phenol increased with a rise in the CD. The increase in the $\mathrm{CD}$ meant an increase in the transmission of electrons, which promoted the redox reactions of the pollutants on the electrodes [21]. However, when the CD surpassed $40 \mathrm{~mA} / \mathrm{cm}^{2}$, the increase in the removal rate of phenol 
was slight and insignificant. These results occurred because the increase in CD generated additional oxygen and hydrogen bubbles, which limited the contact of the pollutants with the electrodes [34]. For maximal energy savings and an appropriate removal rate of phenol, the optimum current density was $50 \mathrm{~mA} / \mathrm{cm}^{2}$. The consumption of electrical energy is represented in the following:

$$
\mathrm{EC}=\frac{V I t}{v}
$$

where EC is the energy consumption $\left(\mathrm{kWh} / \mathrm{m}^{3}\right), \mathrm{V}$ is the voltage $(\mathrm{V}), \mathrm{I}$ is the applied current (A), $\mathrm{t}$ is the electrolysis time ( $\mathrm{min})$, and $\mathrm{v}$ is the volume of wastewater $\left(\mathrm{m}^{3}\right)$. For a CD of $50 \mathrm{~mA} / \mathrm{cm}^{2}$ and an electrolysis time of $30 \mathrm{~min}$, the energy consumption was $6.34 \mathrm{KW} \cdot \mathrm{h} / \mathrm{m}^{3}$.

Fig. 5. Effect of the current density on the removal rate of phenol.

\subsubsection{Effect of electrode plate distance}

The effect of the electrode plate distance was investigated using a 3-6-cm plate distance, phenol concentration $=0.5 \mathrm{~g} / \mathrm{L}, \mathrm{Na}_{2} \mathrm{SO}_{4}=0.25 \mathrm{~g} / \mathrm{L}$, temperature $=45^{\circ} \mathrm{C}, \mathrm{pH}=4, \mathrm{CD}=50$ $\mathrm{mA} / \mathrm{cm}^{2}$, and electrolysis time $=30 \mathrm{~min}$, as illustrated in Fig. 6. The phenol removal rate increased when the distance between the plates was less than $4 \mathrm{~cm}$. When the electrode distance exceeded $4 \mathrm{~cm}$, the removal rate of phenol decreased slightly. This decrease was perhaps due to the decline in the formation of aluminum cations, which resulted from the increment in the ohmic potential. Hence, there was a decrease in the effectiveness of the electrochemical process [35]. The maximum removal rate of phenol was $82 \%$ at the optimum electrode distance of $4 \mathrm{~cm}$.

Fig. 6. Effect of the electrode plate distance on phenol removal.

\subsection{Third granulated electrode experiments}

\subsubsection{Effect of pH}

The effect of the $\mathrm{pH}$ on the removal rate of phenol in the electrochemical cell in the presence of NZVI and SC-NZVI as granulated electrodes was studied at a plate distance $=4 \mathrm{~cm}, \mathrm{CD}=50$ $\mathrm{mA} / \mathrm{cm}^{2}$, phenol concentration $=0.5 \mathrm{~g} / \mathrm{L}, \mathrm{Na}_{2} \mathrm{SO}_{4}=0.25 \mathrm{~g} / \mathrm{L}, \mathrm{NZVI}$ or $\mathrm{SC}-\mathrm{NZVI}=1 \mathrm{~g} / \mathrm{L}$, temperature $=45^{\circ} \mathrm{C}$, and electrolysis time $=30 \mathrm{~min}$. The $\mathrm{pH}$ was adjusted from 2-5, as shown in Fig. 7. The maximum removal rates of phenol decreased at a lower $\mathrm{pH}$ value (i.e., 2.5) and with 
the increment of $\mathrm{pH}$ for both NZVI and SC-NZVI. During the electrolysis process, $\mathrm{H}_{2} \mathrm{O}_{2}$ was produced by the reduction of oxygen at a low $\mathrm{pH}$. An indirect Fenton reaction will occur between ZVI and hydrogen peroxide, producing $\mathrm{OH}$ radicals [36]. In addition, a reduction of $\mathrm{Fe}^{3+}$ to $\mathrm{Fe}^{2+}$ on the cathode electrode will occur. The $\mathrm{OH}$ will combine with the organic pollutants, thereby degrading them. At a very low $\mathrm{pH}$ (i.e., <2), the removal rate of phenol will decline because the saturated hydrogen ions will supply a proton for hydrogen peroxide to form hydroxonium ions (Eq. 3), thus decreasing the activity of the hydrogen peroxide [21]. Furthermore, the strong scavenging action of $\mathrm{H}+$ to $\mathrm{OH}$ (Eq. 4) will be evident [37]. Thus, the optimum $\mathrm{pH}$ value is 2 for both NZVI and SC-NZVI.

$$
\begin{aligned}
& \mathrm{H}_{2} \mathrm{O}_{2}+\mathrm{H}^{+} \longrightarrow \mathrm{H}_{3} \mathrm{O}_{2}^{+} \\
& \dot{\mathrm{OH}}+\mathrm{H}^{+}+\mathrm{e}^{-} \longrightarrow \mathrm{H}_{2} \mathrm{O}
\end{aligned}
$$

Fig. 7. Effect of the $\mathrm{pH}$ on the removal rate of phenol.

\subsubsection{Effect of granular electrode dose}

The influence of the granular electrode dose was investigated using $0.75-2 \mathrm{~g} / \mathrm{L}$ of NZVI or SC-NZVI, plate distance $=4 \mathrm{~cm}, \mathrm{CD}=50 \mathrm{~mA} / \mathrm{cm}^{2}$, phenol concentration $=0.5 \mathrm{~g} / \mathrm{L}, \mathrm{Na}_{2} \mathrm{SO}_{4}=$ $0.25 \mathrm{~g} / \mathrm{L}, \mathrm{pH}=2$, temperature $=45^{\circ} \mathrm{C}$, electrolysis time $=30 \mathrm{~min}$, along with a magnetic stirrer. As demonstrated in Fig. 8, the phenol removal rate increased when the dose of NZVI was less than $1 \mathrm{~g} / \mathrm{L}$ and the dose of SC-NZVI was below $1.25 \mathrm{~g} / \mathrm{L}$. However, a downward trend took place when the doses were larger. The increase in NZVI and SC-NZVI doses led to an increase in the contact chance between the granular electrodes and the phenol molecule, which enhanced the adsorption and reduction of the latter. In addition, this increase in granular electrode doses can support a Fenton reaction. As for the decrease in the removal rate of phenol, there are two possibilities. First, the aggregation could be due to the increasing dose of the adsorbent leading to a decrease in the specific surface area and also a lengthening of the diffusion path of the organic pollutants. Second, because the concentration of phenol was low, the high dose of NZVI or SC-NZVI caused unsaturated adsorption sites and an increase in NZVI or SC-NZVI, which oxidized to $\mathrm{Fe}_{2} \mathrm{O}_{3}$ and $\mathrm{Fe}_{3} \mathrm{O}_{4}$. As a result, the equilibrium adsorption and reduction capacity of NZVI and SC-NZVI decreased when the dosage reached a specific level [38]. The maximum removal rates of phenol using NZVI and SC-NZVI were $96.1 \%$ and $97.8 \%$, respectively. 
Fig. 8. Effect of the granular electrode dose on the removal rate of phenol.

\subsubsection{Effect of phenol concentration}

The influence of the initial phenol concentration was studied using phenol concentrations ranging from 0.5 to $1.5 \mathrm{~g} / \mathrm{L}$. The electrolysis process was conducted with a magnetic stirrer under the following conditions: plate distance $=4 \mathrm{~cm}, \mathrm{NZVI}=1 \mathrm{~g} / \mathrm{L}, \mathrm{SC}-\mathrm{NZVI}=1.25 \mathrm{~g} / \mathrm{L}, \mathrm{Na}_{2} \mathrm{SO}_{4}=$ $0.25 \mathrm{~g} / \mathrm{L}, \mathrm{pH}=2$, temperature $=45^{\circ} \mathrm{C}$, and electrolysis time $=30 \mathrm{~min}$. As illustrated in Fig. 9, the removal rate of phenol decreased gradually as the phenol concentration increased. A possible explanation for this result is that the aluminum oxides that formed during the electrolysis process were insufficient to oxidize all of the additional amounts of the phenol molecules [30].

Fig. 9. Effect of the phenol concentration on the removal rate of phenol.

\subsection{Optimum operating conditions}

The optimal operating circumstances for various examined parameters were obtained for the maximum removal rate of phenol in two cases, as shown in Fig. 10. First, when using only the electrolysis process, where $\mathrm{pH}=4$, electrolysis time $=30 \mathrm{~min}, \mathrm{CD}=50 \mathrm{~mA} / \mathrm{cm}^{2}$, and electrode distance $=4 \mathrm{~cm}$, the removal rate of phenol was $82 \%$. Second, when using the electrolysis process in the presence of granular electrodes (i.e., NZVI or SC-NZVI), the optimum operating conditions were $\mathrm{pH}=2$, electrolysis time $=30 \mathrm{~min}, \mathrm{CD}=50 \mathrm{~mA} / \mathrm{cm}^{2}$, electrode distance $=4 \mathrm{~cm}$, granular electrode doses $(\mathrm{NZVI}=1 \mathrm{~g} / \mathrm{L} ; \mathrm{SC}-\mathrm{NZVI}=1.25 \mathrm{~g} / \mathrm{L})$, and phenol $=0.5 \mathrm{~g} / \mathrm{L}$. The second case provided removal rates of 96.1 and $97.8 \%$ using NZVI and SC-NZVI, respectively.

Fig. 10. Optimum operating conditions for phenol removal.

\subsection{Three-dimensional electrochemical mechanism}

The three-dimensional electrochemical process for organic materials removal is dependent on several parameters, such as the electrode material, current density, properties and concentrations of the pollutant, granular electrode type, and $\mathrm{pH}$ value. Fig. 11 demonstrates a generalized mechanism of the processes (i.e., electrolysis, adsorption, and reduction) that occur in a hybrid 
system and that assist NZVI and SC-NZVI as granular electrodes in an electrochemical reactor for phenol removal.

Due to the low $\mathrm{pH}$ value, the possible reason for phenol degradation was a Fenton-like reaction. The addition of a granular third electrode (i.e., NZVI or SC-NZVI) of a high specific surface area provides an excellent adsorbent for the organic pollutant (i.e., phenol). In addition to adsorption, NZVI or SC-NZVI will reduce the organic pollutant, and mineralization of organics to $\mathrm{CO}_{2}$ and $\mathrm{H}_{2} \mathrm{O}$ will occur.

Oxidation of NZVI or SC-NZVI by $\mathrm{O}_{2}$ and the formation of $\mathrm{Fe}^{2+}$ will take place (Eq. 5) [39]. At strong acidic conditions, a Fenton reaction between either NZVI or SC-NZVI and hydrogen peroxide will occur. Generation of $\mathrm{H}_{2} \mathrm{O}_{2}$ due to the reduction of $\mathrm{O}_{2}$ by $\mathrm{H}^{+}$will take place near the cathode (Eq. 6). Therefore, as a result of the Fenton reaction of $\mathrm{H}_{2} \mathrm{O}_{2}$ with $\mathrm{Fe}^{2+}$, an abundance of -OH with a high oxidation capability is formed (Eq. 7) [40]. Also, the immediate reduction of the generated $\mathrm{Fe}^{3+}$ to $\mathrm{Fe}^{2+}$ creates a cycle of iron ion transformations that decrease NZVI or SCNZVI exhaustion and oxidize organic pollutants effectively [33].

$$
\begin{gathered}
2 \mathrm{Fe}^{0}+\mathrm{O}_{2}+2 \mathrm{H}_{2} \mathrm{O} \longrightarrow 2 \mathrm{Fe}^{2+}+4 \mathrm{OH}^{-} \\
\mathrm{O}_{2}+2 \mathrm{H}^{+}+2 \mathrm{e}^{-} \longrightarrow \mathrm{H}_{2} \mathrm{O}_{2} \\
\mathrm{Fe}^{2+}+\mathrm{H}_{2} \mathrm{O}_{2} \longrightarrow \cdot \mathrm{OH}+\mathrm{OH}^{-}+\mathrm{Fe}^{3+}
\end{gathered}
$$

Fig. 11. Electrochemical processes for organics removal in a 3-D electrochemical reactor.

\section{Comparative study}

A comparative study between this research and the literature can be done by assessing the derived results of the removal rate of phenol using different granular electrodes in hybrid 3-D electrochemical systems, as shown in Table 1. This table illustrates that using nanoparticle zerovalent iron synthesized from modified green tea biowaste and supported on silty clay provides the highest removal rate of aqueous phenol as well as providing the benefit of using eco-friendly materials as a granular third electrode.

Table 1. Phenol removal rate by a 3-D electrochemical system using various granular electrodes 


\section{Conclusions}

In this study, synthesized NZVI and SC-NZVI were successfully used as granular electrodes in an electrochemical reactor. This work revealed that the electrochemical treatment of aqueous phenol using aluminum as the anode and cathode electrodes is an effective method, which produces a maximum phenol removal rate of $82 \%$. The following optimum conditions were determined: $\mathrm{pH}=2$, electrolysis time $=30 \mathrm{~min}$, current density $=50 \mathrm{~mA} / \mathrm{cm}^{2}$, electrode distance $=4 \mathrm{~cm}$, and phenol concentration $=0.5 \mathrm{~g} / \mathrm{L}$. It was proved that either NZVI or SC-NZVI improve the treatment process when they are employed as efficient and effective granular electrodes in hybrid systems. In the hybrid system, the removal rate of phenol increased to 96.1 and $97.8 \%$ using NZVI and SC-NZVI, respectively. This study demonstrated that a 3-D electrode system was an eff ective technology for the treatment of phenolic wastewater in an electrochemical reactor.

\section{Data Availability Statement:}

Raw data were generated at [University of Technology/ Chemical Engineering Department]. Derived data supporting the findings of this study are available from the corresponding author on request.

\section{Competing interests}

The authors declare that they have no known competing financial interests or personal relationships that could have appeared to influence the work reported in this paper.

\section{Funding statement}

This research did not receive any specific grant from funding agencies in the public, commercial, or not-for-profit sectors.

\section{Author contribution statement}

Shaimaa T. Kadhum: Conceived and designed the experiments; Analyzed and interpreted the data.

Ghayda Y. Alkindi: Performed the experiments.

Talib M. Albayati: Contributed reagents, materials, analysis tools or data; Wrote the paper.

\section{Acknowledgments}


The authors gratefully acknowledge the scientific support and help of the Civil Engineering Department and Chemical Engineering Department, University of Technology, Baghdad, Iraq.

\section{References}

1- G. Laura, C. Villegas, N. Mashhadi, M. Chen, D. Mukherjee, Keith E. Taylor, and N. Biswas, A Short Review of Techniques for Phenol Removal from Wastewater, Curr Pollution Rep, 2 (2016) 157-167.

2- T. M. Albayati and K. R. Kalash, Polycyclic aromatic hydrocarbons adsorption from wastewater using different types of prepared mesoporous materials MCM-41in batch and fixed bed column. Process Safety and Environmental Protection 133 (2020) 124-136.

3- Y. A. Abd Al-Khodor, T. M. Albayati, Employing sodium hydroxide in desulfurization of the actual heavy crude oil: Theoretical optimization and experimental evaluation, Process Safety and Environmental Protection 136 (2020) 334-342.

4- Sh. Mohammadi, A. Kargari, H. Sanaeepur, K. Abbassian, A. Najafi, and E. Mofarrah, Phenol removal from industrial wastewaters: a short review, Desalination and Water Treatment, (2014) 1-20.

5- Y. Yavuz, S. Koparal, Electrochemical oxidation of phenol in a parallel plate reaction using ruthenium mixed metal oxide electrode, J. Hazard. Mater. B136 (2006) 292-302.

6- Y. Wang, B. Gu, Electro-catalytic degradation of phenol on several metal-oxide anodes, J. Hazard. Mater, 162 (2009) 1159-1164.

7- M. Shourian, K. Noghabi, H. Zahiri, T. Bagheri, G. Karaballaei, M. Mollaei, I. Rad, S. Ahadi, J. Raheb, H. Abbasi, Efficient phenol degradation by a newly characterized Pseudomonas sp. SA01 isolated from pharmaceutical wastewaters, desalination246 (2009) 577-594.

8- M.H. EL-Naas, S. Al-Zuhair, S. Makhlouf, Batch degradation of phenol in a spouted bed bioreactor system, J. Ind. Eng. Chem, 16 (2010) 267-272.

9- G. Busca, S. Berardinelli, C. Resini, L. Arrighi, Technologies for the removal of phenol from fluid streams, a short review of recent developments, J. Hazard. Mater, 160 (2008) 265-288.

10- A. Agrios, K. Gray, E. Weitz, Photocatalytic transformation of 2,4,5- trichlorophenol on TiO2 under sub-band-gap illumination, Langmuir 19 (2003) 1402-1409. 
11-C. Yang, Y. Qian, L. Zhang, J. Feng, Solvent extraction process development and on-site trial-plant for phenol removal from industrial coal-gasification wastewater, Chem. Eng. J., 117 (2006) 179-185.

12- A.B. Pandit, P.R. Gogate, S. Mujumdar "Ultrasonic degradation of 2:4:6 trichlorophenol in presence of TiO2 catalyst" Ultrason. Sonochem, 8 (2001) 227-231.

13- I.D. Buchanan, J.A. Micell, Peroxidase catalyzed removal of aqueous phenol, Biotechnol. Bioeng, 54 (1997) 251-261.

14- MI. Pariente, R. Molina, JA. Melero, JÁ. Botas, F. Martínez, Intensified-Fenton process for the treatment of phenol aqueous solutions, Water Sci Technol, 71(3) (2015) 359-65.

15- A. Mohd Din, B.H. Hameed, A.L. Ahmed, Batch adsorption of phenol onto physicochemical-activated coconut shell, J. Hazard. Mater, 161 (2009) 1522-1529.

16- J.M. Valente Nabais, J.A. Gomes Suhas, P.J.M. Carrott, C. Laginhas, S. Roman, Phenol removal onto novel activated carbons made from lignocellulosic precursors: influence of surface properties, J. Hazard. Mater, 167 (2009) 904-910.

17- P. H. Britto-Costa, and L. A. M. Ruotolo, Phenol removal from wastewater by electrochemical oxidation using boron doped diamond (BDD) and $\mathrm{Ti} / \mathrm{Ti}_{0.7} \mathrm{Ru}_{0.3} \mathrm{O}_{2}$ DSA electrodes, Brazilian Journal of Chemical Engineering, 29 (4) (2012) 763-773.

18- Pillai IM, Gupta AK, Batch and continuous flow anodic oxidation of 2,4-dinitrophenol: modeling, degradation pathway and toxicity, J Electroanal Chem, (2015) 108-117.

19-S. Garcia-Segura, D. Ocon, C. Meng Nan, Electrochemical Oxidation Remediation of Real Wastewater Effluents - A review, Process Safety and Environment Protection, 113 (2018) 48-67.

20- E. Brillas, C.A. Martínez-Huitle, Decontamination of wastewaters containing synthetic organic dyes by electrochemical methods. An updated review, Appl. Catal. B: Environ., 166-167 (2015) 603-643.

21- C. Zexu, Z. Wang, C. Huanqing, B. Pingping, and L. Lucia, Bentonite-supported nanoscale zero valent iron granulated electrodes for industrial wastewater remediation, Royal Society of Chemistry, 7 (2017) 44605-44613.

22- Z. Yang, X. Qiu, Z. Fang, and T. Pokeung, Transport of nano zero-valent iron supported by mesoporous silica microspheres in porous media, Water Science \& Technology, 17.12 (2015)1800-1805. 
23- C. Zhang, L. Zhou, J. Yang, X. Yu, Y. Jiang, M. Zhou, Nanoscale zero-valent iron/AC as heterogeneous Fenton catalysts in three-dimensional electrode system, Environmental Science and Pollution Research, 21 (2014) 8398-8405.

24- S. Bang, GP. Korfiatis, X. Meng, Removal of arsenic from water by zero-valent iron, J Hazard Mater, 121 (2005) 61-67.

25- B. Yang, and J. Tang, Electrochemical oxidation treatment of wastewater using activated carbon electrode, Int. J. Electrochem. Sci., 13 (2018) 1096-1104.

26- L. Yan, H. Ma, B. Wang, Y. Wang, Y. Chen, Electrochemical treatment of petroleum refinery wastewater with three-dimensional multi-phase electrode, Desalination, 276 (2011) 397-400.

27- P. Canizares, J. Lobato, J. Garcia-Gomez and M.A. Rodrigo, Combined adsorption and electrochemical processes for the treatment of acidic aqueous phenol wastes, Journal of Applied Electrochemistry, 34 (2004) 111-117.

28- S. Singh, S. Mahesh, and M. Sahana, Three-dimensional batch electrochemical coagulation (ECC) of health care facility wastewater-clean water reclamation, Environmental Science and Pollution Research, 26 (2019) 12813-12827.

29-Y. Meng, Y. Fangrong, C. Yige, L. Jujie, and Li Ziyan, A three-dimensional electrochemical oxidation system with a-Fe2O3/PAC as the particle electrode for ammonium nitrogen wastewater treatment, Royal Society of Chemistry, 10 (2020) 87738779.

30- O. Abdelwahab, N.K. Amin, E-S.Z. El-Ashtoukhy, Electrochemical removal of phenol from oil refinery wastewater, Journal of Hazardous Material, 163 (2009) 711-716.

31- N. Adhoum, L. Monser, Decolorization and removal of phenolic compounds from olive mill wastewater by electrocoagulation, Chem. Eng. Process. 43 (2004) 1281-1287.

32- J. Zhu, H. Zhao, J. Ni, Fluoride distribution in electrocoagulation defluoridation process, Sep. Purif. Technol, 56 (2007) 184-191.

33- Z. Chi, Z. Wang, Y. Liu, G. Yang, Preparation of organosolv lignin-stabilized nano zerovalent iron and its application as granular electrode in the tertiary treatment of pulp and paper wastewater, Chemical Engineering Journal, 331 (2018) 317-325.

34- C. Wang, Y.K. Huang, Q. Zhao, M. Ji, Treatment of secondary effluent using a threedimensional electrode system: COD removal, biotoxicity assessment and disinfection effects, Chem. Eng. J., 243 (2014) 1-6. 
35- O. Sahu, Electro-oxidation and chemical oxidation treatment of sugar industry wastewater with ferrous material: An investigation of physicochemical characteristic of sludge, South African Journal of Chemical Engineering, 28 (2019) 26-38.

36- X. H. L. Thi, M. Bechelany, J. Champavert and M. Cretin, A highly active based graphene cathode for the electro-Fenton reaction, RSC Adv., 5 (2015) 42536-42539.

37- H. Shemer, K. G. Linden, Degradation and by-product formation of diazinon in water during UV and $\mathrm{UV} / \mathrm{H}_{2} \mathrm{O}_{2}$ treatment, Journal of Hazardous Materials, B136 (2006) 553559.

38- M. Basha Allabaksh, B. Kumar Mandal, M. Kumar Kesarla, K. Siva Kumar, and P. Sreedhara Reddy, Preparation of Stable Zero Valent Iron Nanoparticles using Different Chelating Agents, J. Chem. Pharm. Res., 2(5) (2010) 67-74.

39- A. Shimizu, M. Tokumura, K. Nakajima, Y. Kawase, Phenol removal using zerovalent iron powder in the presence of dissolved oxygen: roles of decomposition by the Fenton reaction and adsorption/precipitation, J. Hazard. Mater. 2s201-202 (2012) 60-67.

40- E. Brillas, I. Sirés, M.A. Oturan, Electro-Fenton process and related electrochemical technologies based on Fenton's reaction chemistry, Chem. Rev. 109 (2009) 6570-6631.

41- Y. Xia, L. Yafeng, C. Lin, Experimental study on the oxidation degradation of phenol wastewater by three-dimensional electrode. Industrial Water Treatment, 30(5) (2010) 2729.

42- L. Zhigang, S. Wei, L. Yansheng, Z. Shaomin, Continuous electrochemical oxidation of phenol using a three-dimensional electrode reactor, Applied Mechanics and Materials, 71-78 (2011) 2169-2172.

43- N. Song, Z. Zhaoxi, Experimental Study on the Oxidation Degradation of Phenolic Compound from Refinery Wastewater by Three-dimensional Electrode, Advances in Fine Petrochemicals, 12(5) (2011) 28-31.

44- N. Qiao, H. Ma, and M. Hu, Design of a neutral three-dimensional electro-Fenton system with various bentonite-based Fe particle electrodes: A comparative study, Materials Research Innovations, 19 (2015) 137-141.

45- L. Ping, C. Wangfeng, X. Yue., Y. Wang, F. Jiangyang, Electrochemical Degradation of Phenol Wastewater by Sn-Sb-Ce Modified Granular Activated Carbon, Int. J. Electrochem. Sci., 12 (2017) 2777 - 2790. 


\section{Figures}

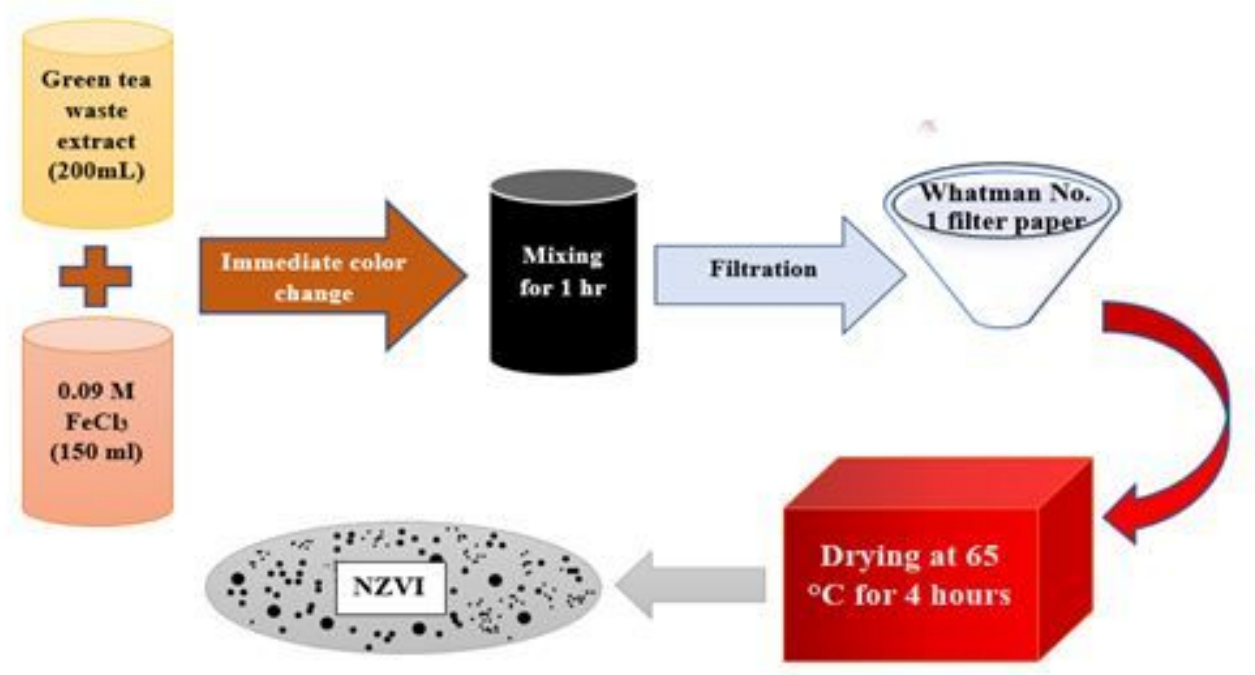

(a)

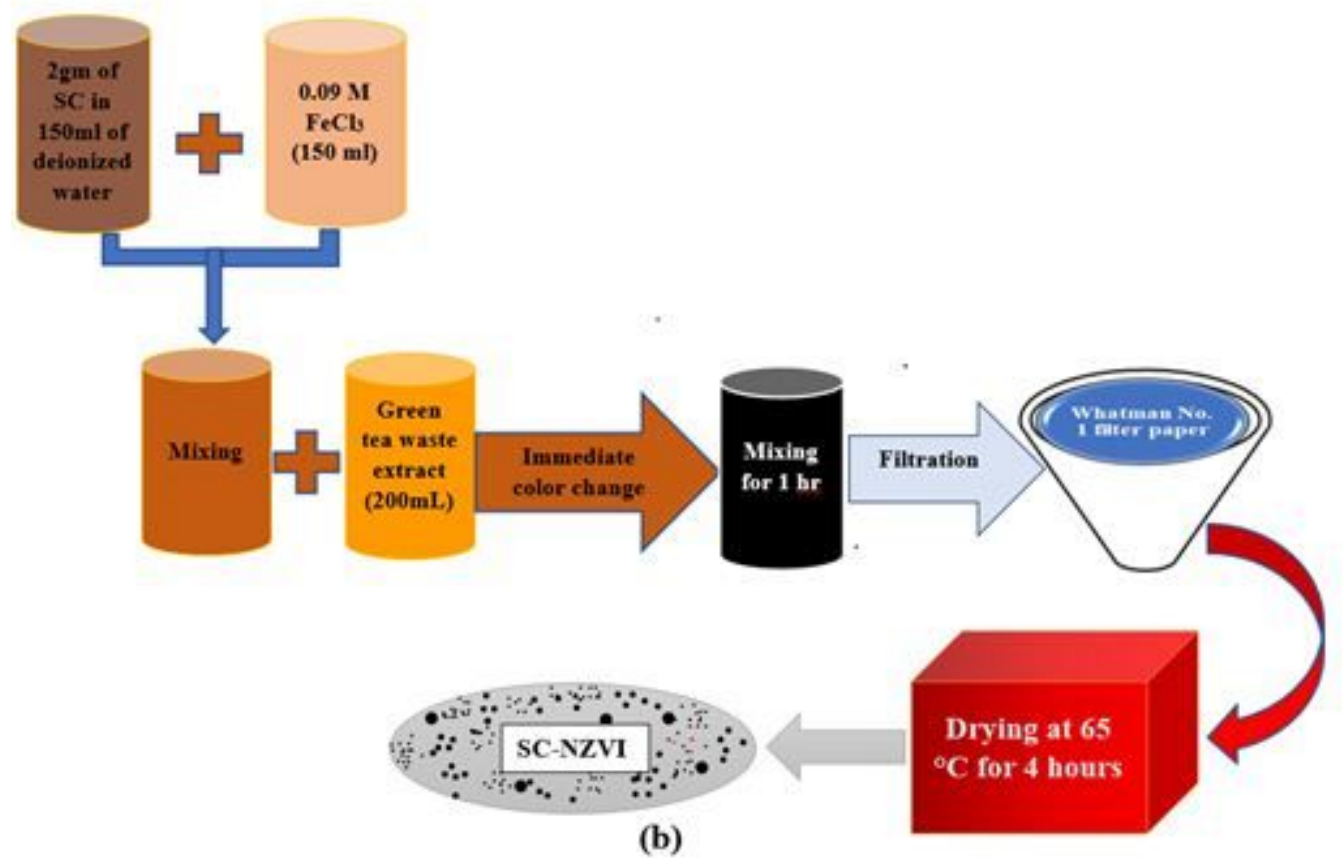

Figure 1

Synthesis methods of (a) NZVI and (b) SC-NZVI. 


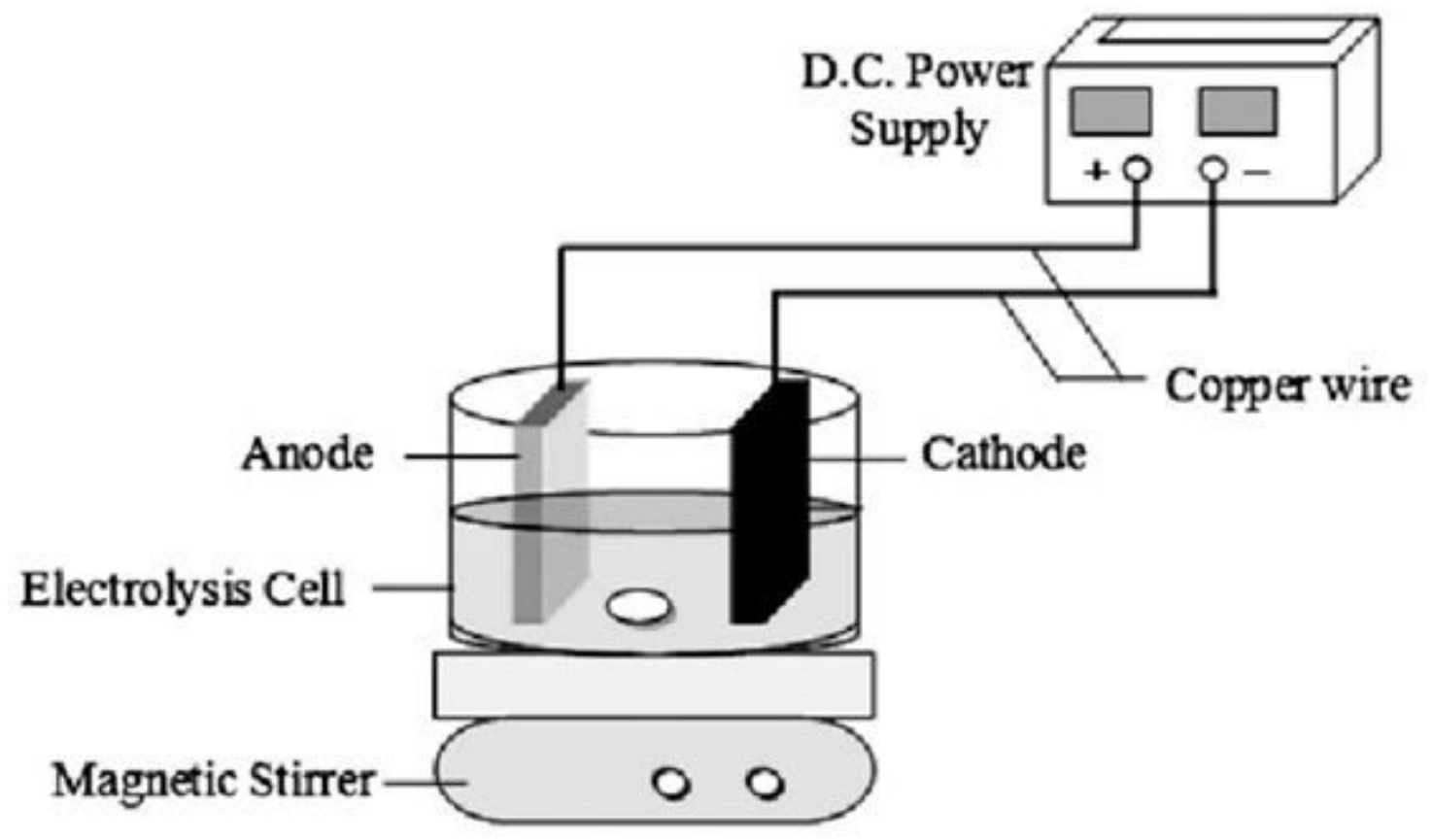

Figure 2

Electrochemical apparatus.

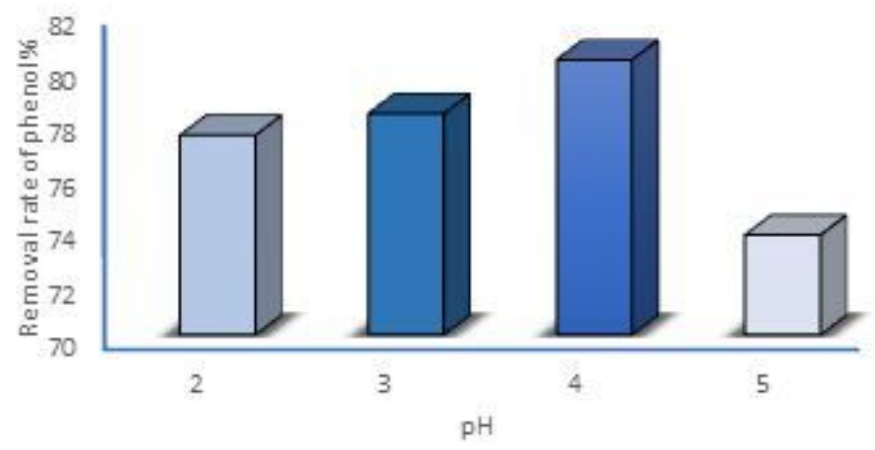

Figure 3

Effect of $\mathrm{pH}$ on the phenol removal percentage. 


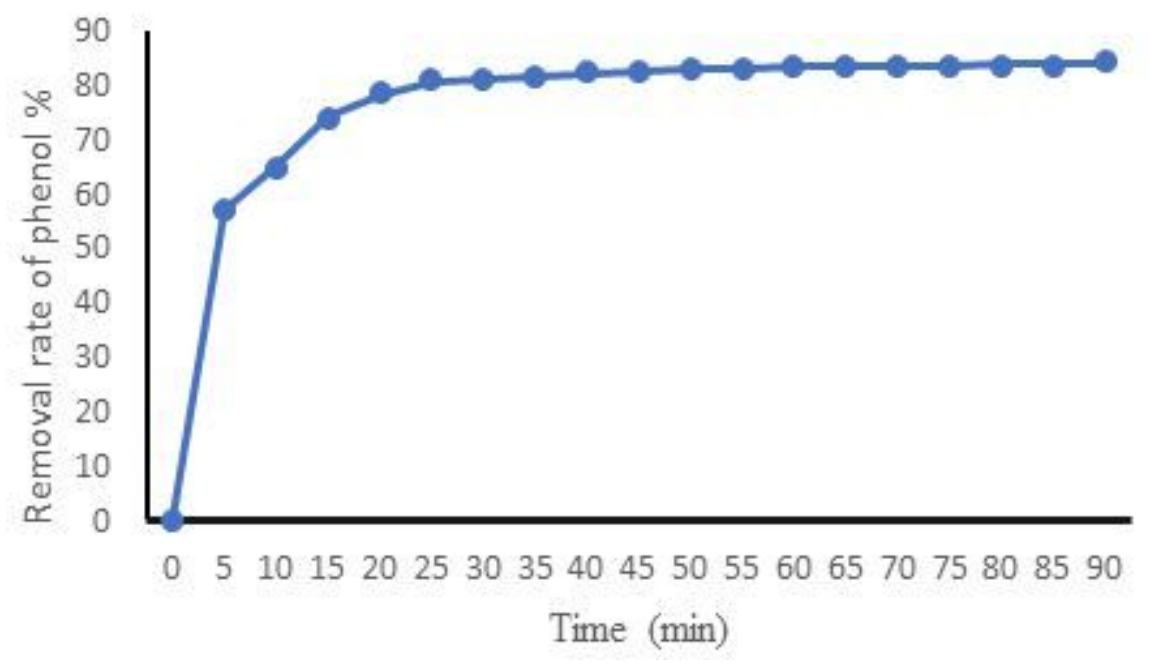

Figure 4

Effect of the electrolysis time on the removal rate of phenol.

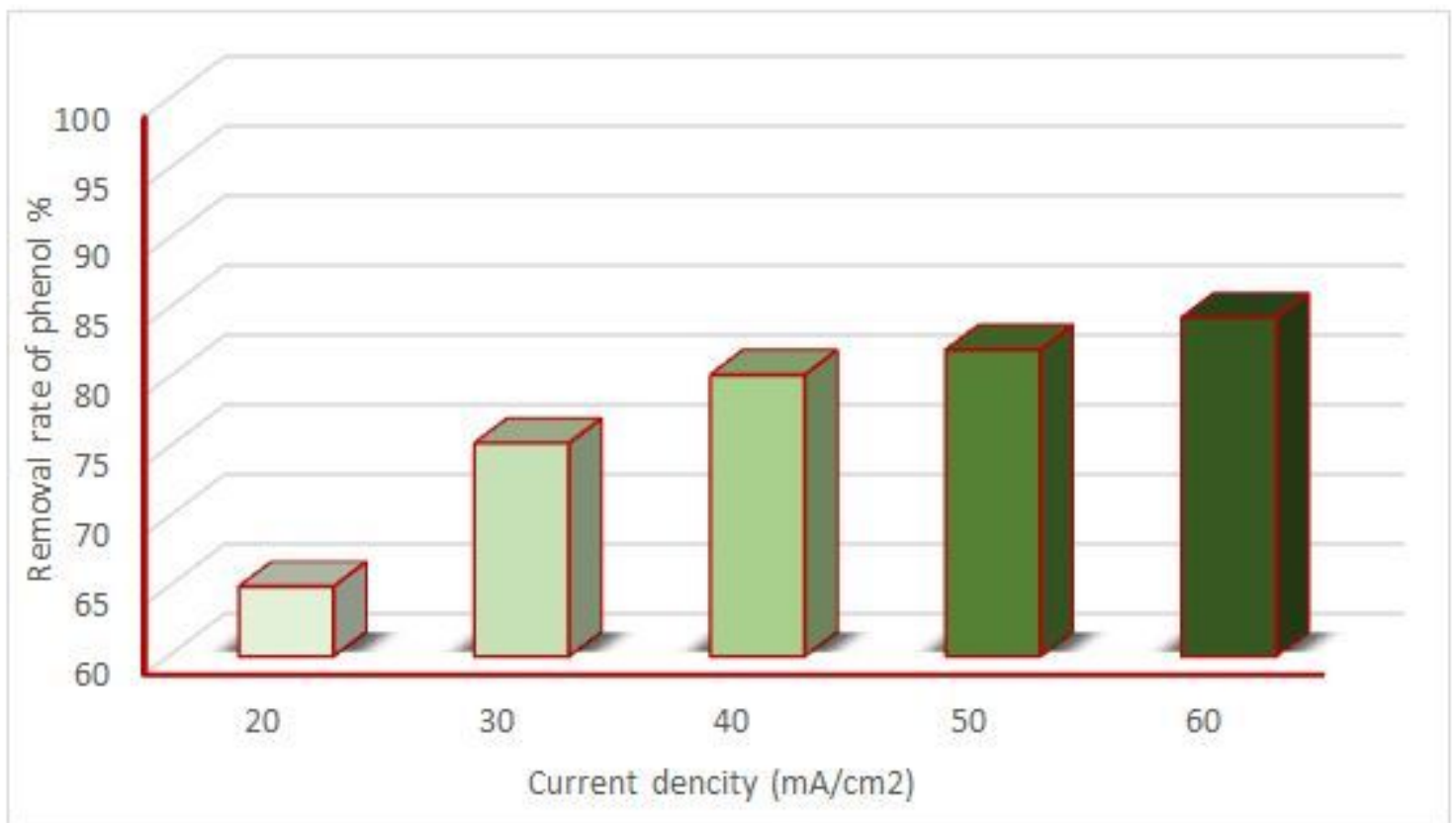

Figure 5

Effect of the current density on the removal rate of phenol. 


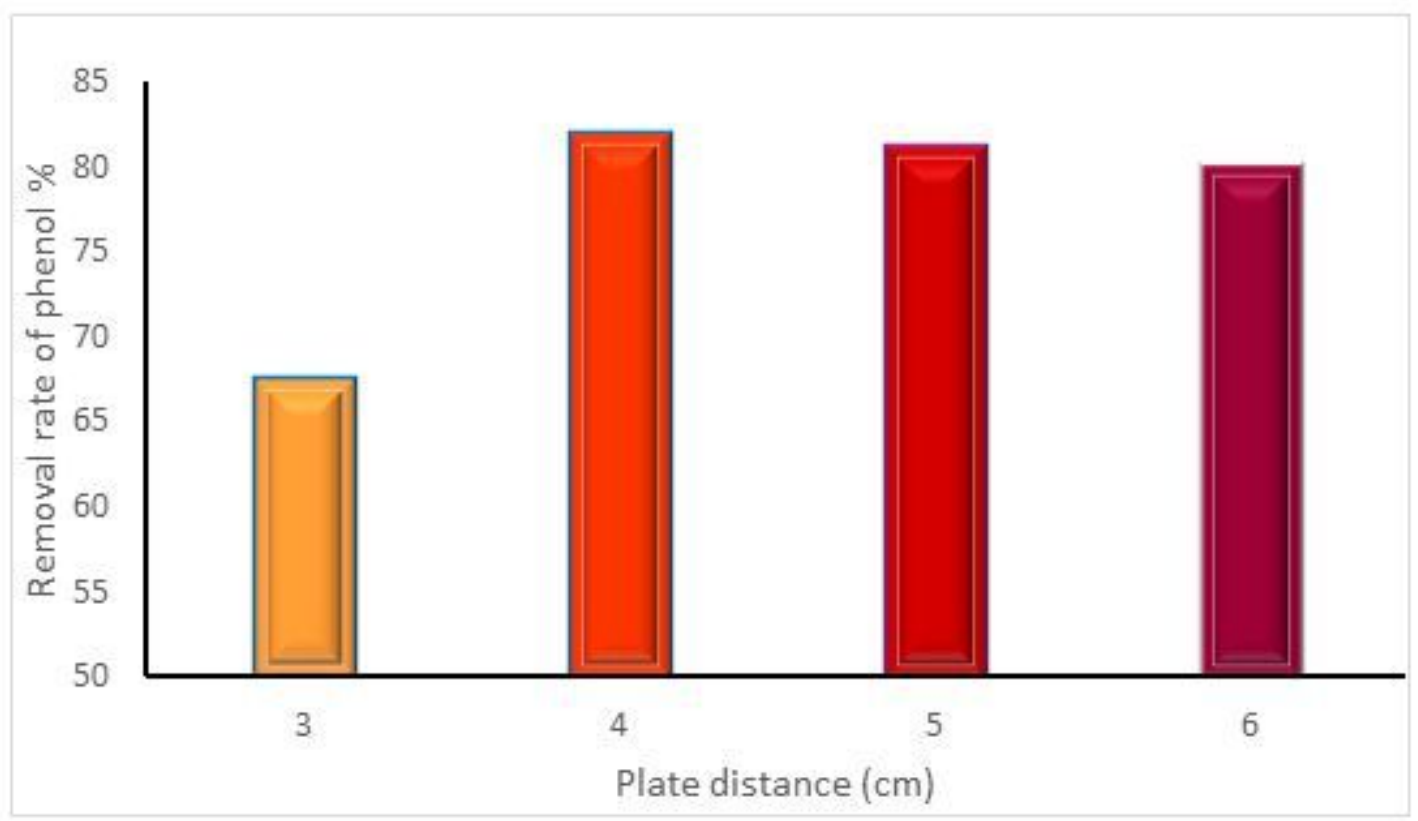

Figure 6

Effect of the electrode plate distance on phenol removal.

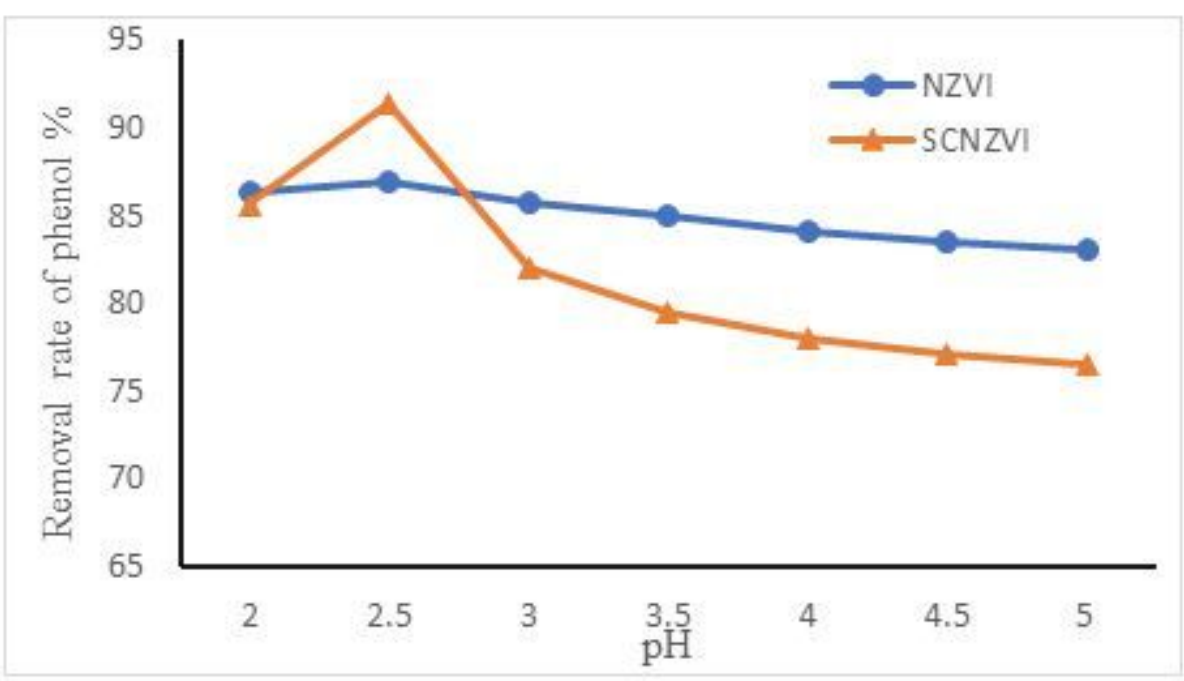

Figure 7

Effect of the $\mathrm{pH}$ on the removal rate of phenol. 


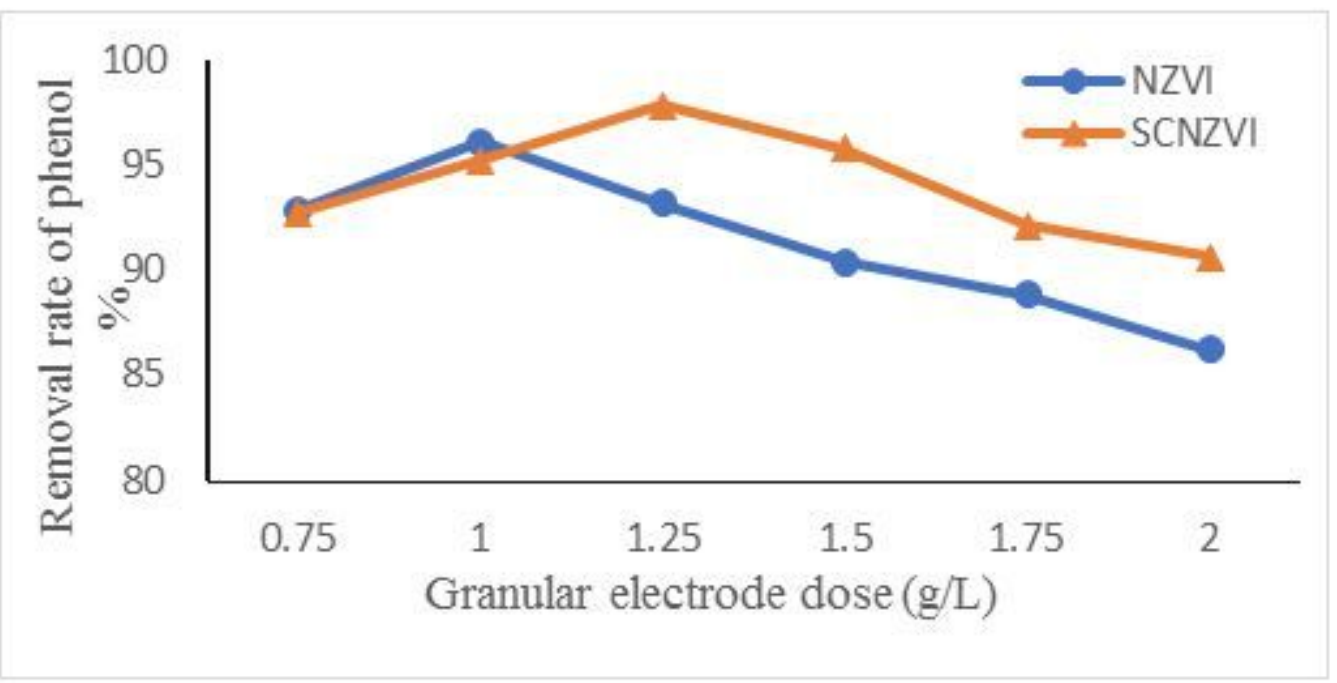

\section{Figure 8}

Effect of the granular electrode dose on the removal rate of phenol.

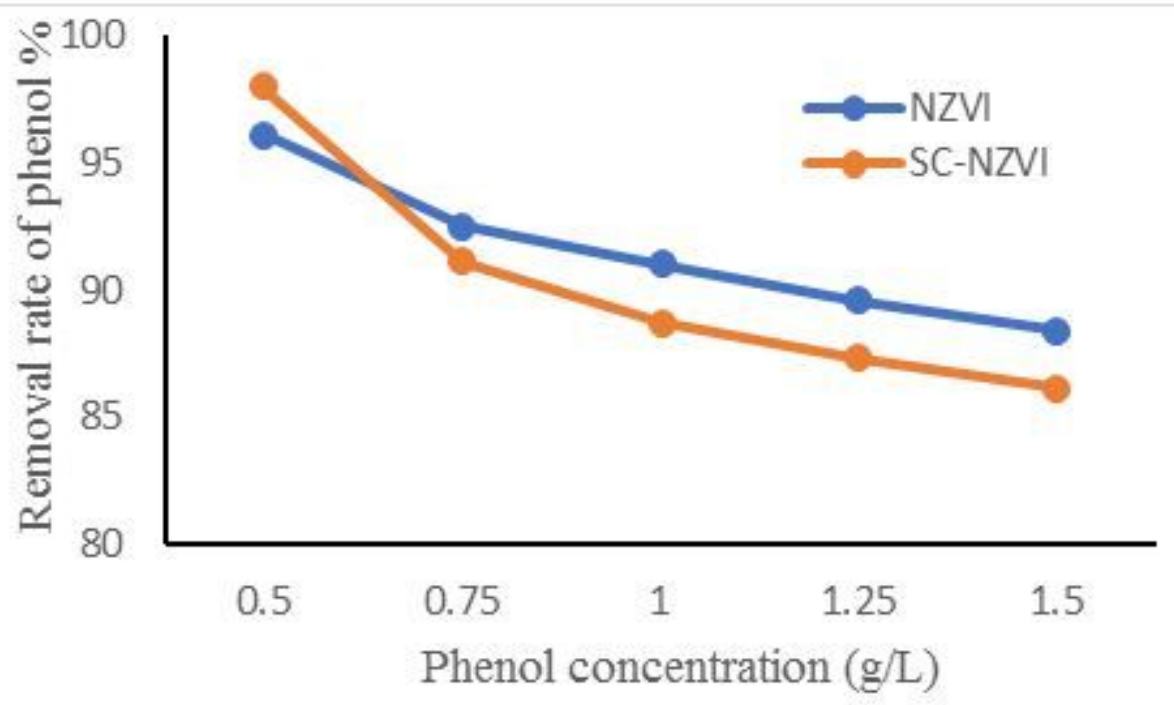

Figure 9

Effect of the phenol concentration on the removal rate of phenol. 


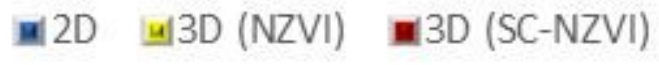

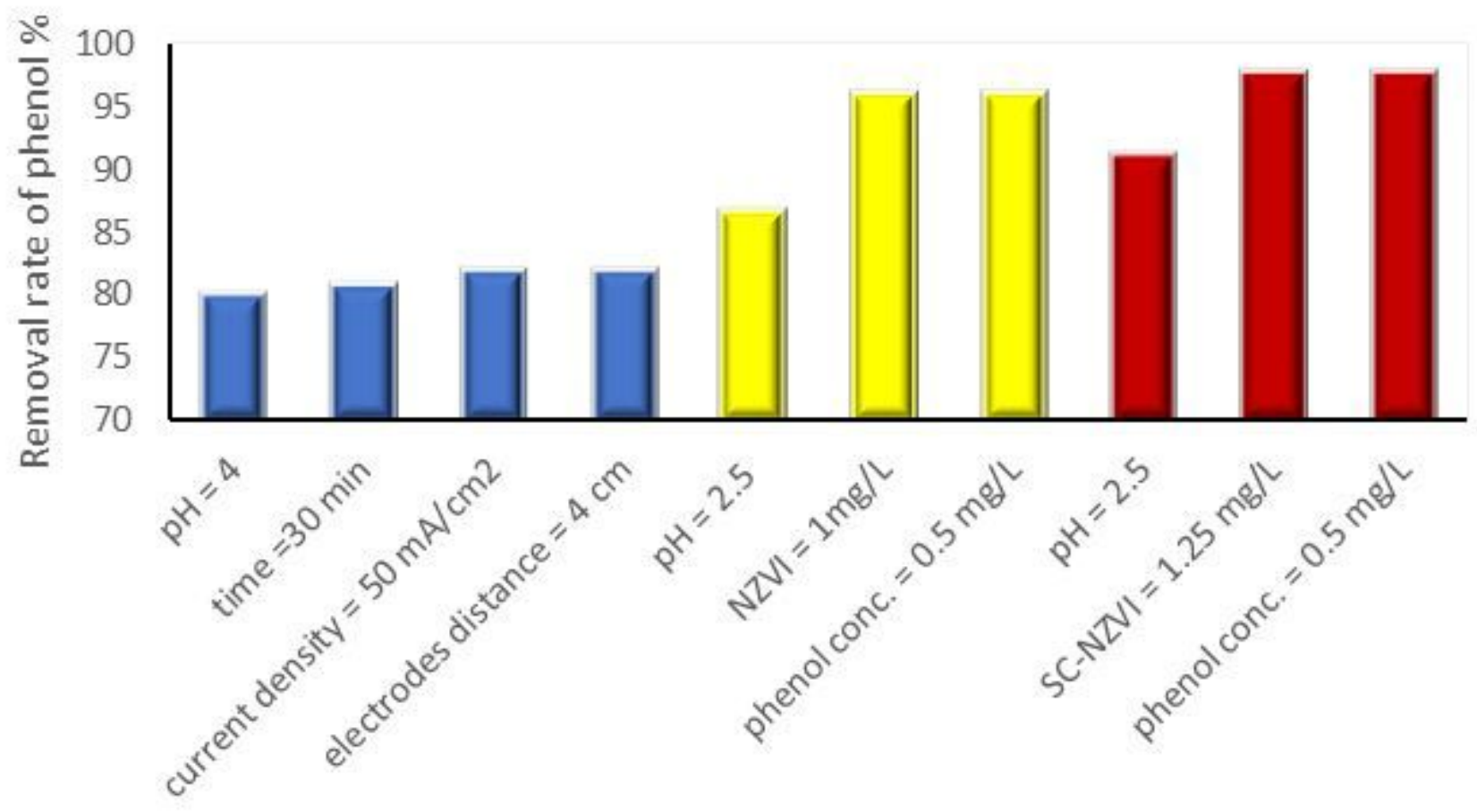

Figure 10

Optimum operating conditions for phenol removal.
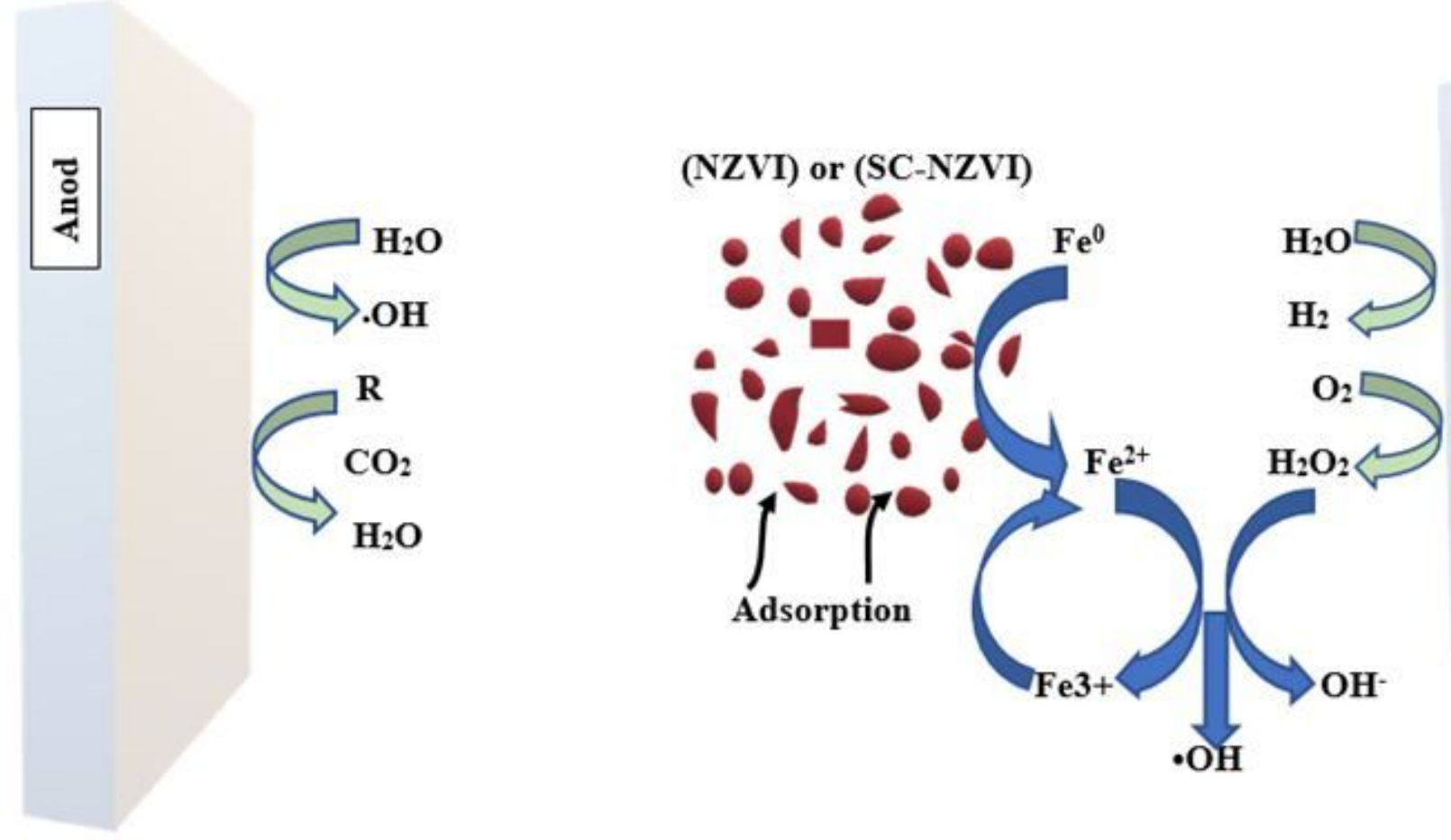

Figure 11 
Electrochemical processes for organics removal in a 3-D electrochemical reactor. 